\title{
Pengaruh Paparan Gas Ozon terhadap Jumlah Koloni Jamur Candida albicans
}

\author{
Amana F. Chusaeni, Gunawan Wibisono, Tira H. Skripsa
}

\author{
Departemen Kedokteran Gigi Fakultas Kedokteran Universitas Diponegoro, Semarang, \\ Indonesia \\ Email: amanafitria@students.undip.ac.id; gunawanwibisono_drg@yahoo.com
}

\begin{abstract}
Candida albicans is one of the pathogenic fungal species which causes oral infections. One of the methods to minimize the risk of fungal infection is by application of asepsis procedure through gargling with antiseptics. Ozone has high oxidative properties, therefore, it is considered as an antiseptic agent. Plasma Study Center of Diponegoro University has developed an ozone generator machine which opens up an opportunity to identify ozone properties as an antiseptic in controlling the number of fungal colonies, especially Candida albicans. This study was aimed to identify the effects of ozone exposure on the number of fungal colonies of Candida albicans. This was a laboratory experimental study with one-group pretest-posttest design. A total of 32 samples of Candida albicans suspensions were divided into two groups (16 each). Group 1 was not treated with ozonation, while group 2 were ozonated. Then, the two groups were cultured in SDA media using the spread plate method and were incubated for 48 hours. The data were obtained by calculating the number of fungal colonies growing in SDA media. The Wilcoxon test obtained a p-value $<0.05$, meaning that there were differences in the colony number of Candida albicans before and after ozonation. In conclusion, ozone exposure has a significant effect on the number of fungal colonies of Candida albicans. Further studies are needed adding variables or parameters.
\end{abstract}

Keywords: ozone; fungal colony; Candida albicans

\begin{abstract}
Abstrak: Candida albicans merupakan salah satu spesies jamur patogen yang menyebabkan infeksi oral. Salah satu metode untuk meminimalkan risiko infeksi jamur ialah melalui penerapan prosedur asepsis dengan berkumur menggunakan antiseptik. Ozon memiliki kemampuan oksidasi tinggi sehingga dipertimbangkan untuk menjadi bahan antiseptik. Pusat Penelitian Plasma Universitas Diponegoro telah mengembangkan mesin generator ozon yang membuka peluang untuk mengetahui kemampuan ozon sebagai antiseptik dalam mengendalikan jumlah koloni jamur terutama Candida albicans. Penelitian ini bertujuan untuk mengetahui adanya pengaruh paparan gas ozon terhadap jumlah koloni jamur (Candida albicans). Jenis penelitian ialah eksperimental laboratorik dengan one group pretest-posttest design. Sebanyak 32 sampel suspensi jamur Candida albicans dibagi menjadi dua kelompok (masing-masing 16 sampel). Kelompok 1 tidak dilakukan ozonasi dan kelompok 2 dilakukan ozonasi kemudian kedua kelompok dikultur dalam media SDA dengan metode spread plate dan diinkubasi 48 jam. Data diperoleh dengan menghitung jumlah koloni jamur yang tumbuh pada media SDA. Hasil uji statistik Wilcoxon mendapatkan nilai $\mathrm{p}<0,05$ yang berarti terdapat perbedaan jumlah koloni jamur (Candida albicans) sebelum dan setelah pemberian gas ozon. Simpuolan penelitian ini ialah paparan gas ozon berpengaruh secara bermakna terhadap jumlah koloni jamur (Candida albicans). Penelitian lanjutan diperlukan dengan penambahan variabel atau parameter.
\end{abstract}

Kata kunci: gas ozon; koloni jamur; Candida albicans

\section{PENDAHULUAN}

Penyakit infeksi adalah suatu penyakit yang disebabkan oleh mikroba patogen. ${ }^{1,2}$
Salah satu jenis mikroba tersebut ialah jamur patogen. ${ }^{3}$ Kejadian infeksi jamur telah 
meningkat tinggi selama beberapa dekade terakhir. ${ }^{4}$ Sejak tahun 2013, Leading International Fungal Education (LIFE) melaporkan bahwa lebih dari 5.7 miliar orang atau lebih dari $80 \%$ populasi dunia mengalami infeksi jamur yang serius. Prevalensi angka kejadian infeksi jamur di rongga mulut di Indonesia mengalami peningkatan tiap tahunnya yaitu sekitar $50 \%-80 \% .^{5}$

Pada klinik gigi, rongga mulut merupakan sumber utama infeksi jamur secara silang. ${ }^{6}$ Cairan tubuh dari pasien di rongga mulut yang mengandung jamur berpotensi menyebar ke operator, alat kritis, ruangan, dan pasien berikutnya melalui droplet dan bioaerosol. ${ }^{7}$ Hal tersebut dibuktikan dengan ditemukannya jamur patogen pada air dari peralatan perawatan gigi yang telah digunakan. Air tersebut memberikan kondisi yang sesuai untuk tumbuhnya biofilm jamur yang dapat memfasilitasi kontaminasi jamur. Spesies yang sering terlibat dalam etiologi infeksi jamur pada prosedur gigi adalah Candida sp. dan Cryptococcus sp. ${ }^{8}$

Candida merupakan salah satu genus flora normal rongga mulut. Candida dikenal sebagai mikroorganisme oportunistik yang pada kondisi tertentu mampu menyebabkan infeksi dan kerusakan jaringan. ${ }^{9,10}$ Menurut Merino-Alado et $\mathrm{al}^{11}$ pada tahun 2018 melaporkan bahwa persentase jumlah koloni Candida albicans yang diisolasi dari sikat gigi mencapai $87,5 \%$, paling tinggi jika dibanding Candida krusei sebanyak 37,5\%, serta Candida dubliniensis dan Candida glabrata, masing-masing sebanyak $12,5 \% .^{11}$

Salah satu strategi untuk meminimalkan risiko penyebaran jamur patogen secara silang ialah penerapan prosedur asepsis pada praktik dokter gigi. Salah satu bentuk prosedur asepsis pada pasien ialah berkumur dengan menggunakan antiseptik sebelum pemeriksaan atau tindakan. ${ }^{12}$ Hal ini bertujuan untuk mengurangi jumlah mikroba di rongga mulut baik dalam bentuk bioaerosol, droplet, darah, maupun cairan tubuh lainnya dengan cara melarutkan dan membuang mikroba bersamaan dengan saliva dan larutan kumur. ${ }^{13}$

Masalah yang timbul dari penggunaan bahan antiseptik ialah timbulnya risiko berkembangnya jamur dan resistensi terhadap antiseptik, timbulnya rasa yang tidak menyenangkan, perubahan persepsi rasa pada penggunaan jangka panjang, dan diskolorasi gigi. ${ }^{14-16}$ Kemampuan antimikroba dari antiseptik dapat dibuktikan dengan adanya kemampuan oksidasi yang dimiliki. Kemampuan oksidasi tersebut salah satunya dimiliki oleh ozon. ${ }^{17}$

Ozon adalah molekul triatomik, yang terdiri dari tiga atom oksigen. ${ }^{18}$ Kemampuan oksidasi ozon yang tinggi membuat ozon dipertimbangkan untuk menjadi bahan antimikroba dan antiseptik. Ozon dapat digunakan dalam bentuk gas atau dilarutkan dalam air dan keberadaan air dapat meningkatkan reaktivitas dari ozon. ${ }^{19}$

Penggunaan ozon dalam prosedur asepsis pada praktik dokter gigi khususnya di Indonesia, belum pernah dilakukan. Hal ini dapat disebabkan karena minimnya ketersediaan generator ozon di Indonesia. Saat ini telah tersedia mesin generator ozon hasil pengembangan oleh Pusat Penelitian Plasma Universitas Diponegoro, ${ }^{20}$ yang membuka peluang untuk mengetahui kemampuan ozon dalam mengendalikan jumlah koloni jamur seperti Candida albicans. Berdasarkan hal tersebut, penelitian ini dilakukan untuk mengetahui adanya pengaruh paparan gas ozon terhadap jumlah koloni jamur Candida albicans.

\section{METODE PENELITIAN}

Jenis penelitian ini ialah eksperimental laboratorik dengan one group pretestposttest design. Sampel penelitian ini ialah isolat murni jamur $C$. albicans yang diperoleh dari Laboratorium Sentral Rumah Sakit Nasional Diponegoro (RSND) Bagian Mikrobiologi, Semarang. Kriteria inklusi penelitian ini ialah koloni $C$. albicans yang tumbuh pada media Saboroud dextrose agar (SDA) yang diinkubasi selama 48 jam pada suhu $37^{\circ} \mathrm{C}$ dan kriteria eksklusi penelitian ini ialah koloni $C$. albicans yang tumbuh pada media SDA disertai pertumbuhan kontaminan lain. Variabel bebas dari penelitian ini ialah paparan gas ozon sedangkan variabel terikat ialah jumlah koloni jamur C. albicans.

Prosedur penelitian ini dimulai dengan 
permohonan izin penelitian dan ethical clearance pada Komisi Etik Penelitian Kesehatan Fakultas Kedokteran Universitas Diponegoro dengan No. 108/EC/H/FKUNDIP/XI/2020.

Persiapan sampel dilakukan dengan mengkultur isolat $C$. albicans pada media SDA selama 24 jam pada suhu $37^{\circ} \mathrm{C}$. setelah itu dilakukan preparasi suspensi $C$. albicans $0,5-2,5 \times 10^{6} \mathrm{CFU} / \mathrm{mL}$, dengan mensuspensikan isolat dalam $9 \mathrm{~mL} \mathrm{NaCl} 0,9 \%$ dan dibandingkan dengan McFarland $\left(1,5 \times 10^{6}\right.$ $\mathrm{CFU} / \mathrm{mL}$ ). Persiapan alat dilakukan dengan mempersiapkan generator ozon (M-Ozone) nomor seri 02MOOB19 serta mengatur flowmeter pada skala $0.6 \mathrm{~L} / \mathrm{min}$ dan konsentrasi sebesar $400 \mathrm{mg} / \mathrm{L}$.

Semua prosedur dilakukan pada laminar air flow dan didekatkan dengan Bunsen untuk menjaga kesterilan alat dan bahan yang digunakan. Kultur suspensi jamur C. albicans dan perhitungan koloni sebelum perlakuan dilakukan dengan mengambil $5 \mu \mathrm{L}$ dari masing-masing 16 sampel suspensi $C$. albicans dan diinokulasikan pada media SDA dengan metode spread plate. Kultur diiinkubasi pada suhu $37{ }^{\circ} \mathrm{C}$ selama 48 jam.

Keenambelas sampel suspensi $C$. albicans yang lain sebanyak $5 \mathrm{~mL}$ diozonasi menggunakan mesin generator ozon selama 210 detik dengan konsentrasi $400 \mathrm{mg} / \mathrm{L}$. Selanjutnya, 16 sampel tersebut dikultur dan dilakukan perhitungan koloni setelah perlakuan dengan prosedur yang sama seperti sebelum perlakuan.

Setelah didapatkan data berupa jumlah koloni jamur (Candida albicans) sebelum dan setelah perlakuan, data tersebut dilakukan uji normalitas menggunakan uji Shaphiro Wilk. Jika data berdistribusi normal maka dilanjutkan dengan uji $\mathrm{T}$ berpasangan untuk menjawab hipotesis penelitian. Namun bila data tidak terdistribusi normal, maka digunakan analisis data non parametrik dengan uji Wilcoxon.

\section{HASIL PENELITIAN}

Setelah dilakukan penelitian terhadap jumlah koloni jamur Candida albicans sebelum (pre-test) dan sesudah diberi perlakuan (post-test) berupa ozonasi dengan konsentrasi gas ozon $400 \mathrm{mg} / \mathrm{L}$ dan didapatkan hasil seperti yang disajikan pada Tabel 1 .

Tabel 1. Hasil perhitungan jumlah koloni jamur C. albicans sebelum dan setelah dilakukan ozonasi

\begin{tabular}{ccc}
\hline & $\begin{array}{c}\text { Jumlah Koloni Jamur } \\
(\mathbf{C F U} / \mathbf{m l})\end{array}$ \\
& ${\text { Pre-test }\left(\mathbf{1 0}^{\mathbf{3}}\right)}^{\text {Prost-test }}$ \\
\hline $\bar{x} \pm$ S.D. & $13812,5 \pm 6039,6$ & $0 \pm 0$ \\
Minimum & 7600 & 0 \\
Maksimum & 28800 & 0 \\
\hline
\end{tabular}

Gambar 1 memperlihatkan hasil perhitungan koloni jamur $C$. albicans pada media SDA sebelum dan setelah perlakuan berupa ozonasi selama 210 detik.

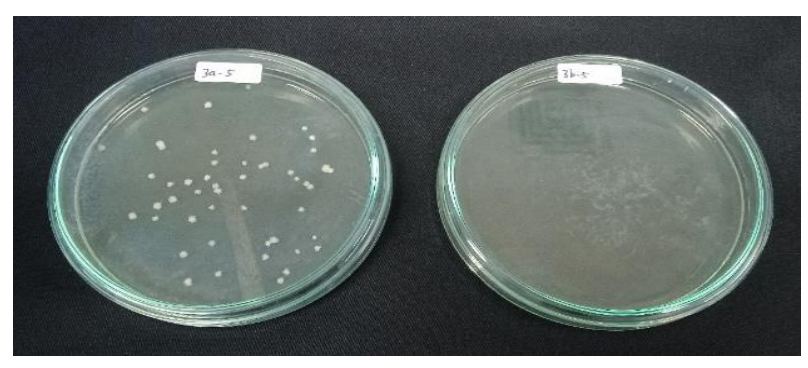

Gambar 1. Hasil kultur suspensi $C$. albicans pada media SDA sebelum dan setelah perlakuan

Hasil penelitian dilakukan uji asumsi sebaran data untuk mengetahui normalitas menggunakan uji Shapiro Wilk dan didapatkan nilai $\mathrm{p}=0,022(\mathrm{p}<0,05)$ yang menunjukkan data terdistribusi tidak normal. Hasil uji normalitas Shapiro-Wilk kelompok posttest bersifat konstan sehingga diabaikan pada uji normalitas tersebut. Karena data terdistribusi tidak normal, maka selanjutnya dilakukan uji Wilcoxon untuk mengetahui perbedaan rerata dua kelompok yang berpasangan seperti yang ditampilkan pada Tabel $2 .^{21}$

Berdasarkan hasil Uji Wilcoxon, pemberian gas ozon menghasilkan perbedaan rerata jumlah koloni jamur $C$. albicans antara kelompok pre-test dan post-test, yaitu sebesar 13812,5 dan 0 secara berturut-turut. Nilai p yang didapatkan sebesar 0,000 $(<0,05)$ sehingga hal tersebut memberikan bukti bahwa paparan gas ozon berpengaruh secara bermakna terhadap jumlah koloni jamur $C$. albicans. $Z$ value sebesar $-3,516$ 
$(\mathrm{z}<-1,96)$ menunjukkan bahwa hipotesis kerja diterima dan juga membuktikan bahwa paparan gas ozon berpengaruh secara bermakna terhadap jumlah koloni jamur $C$. albicans.

Tabel 2. Hasil Uji Wilcoxon

\begin{tabular}{cccc}
\hline Perlakuan & $\overline{\boldsymbol{x}}$ & $\mathbf{z}$ & Nilai p \\
\hline Pre-test & 13812,5 & $-3,516$ & $<0,05$ \\
Post-test & 0 & & \\
\hline
\end{tabular}

\section{BAHASAN}

Aktivitas antiseptik ozon merupakan hasil dari aksi pada sel dengan merusak membran sitoplasma yang menyebabkan ozonolysis ikatan rangkap. Selain itu, induksi ozon dapat memodifikasi komponen intrasel karena adanya efek oksidasi sekunder. ${ }^{22}$ Modifikasi komponen intrasel seperti fosfolipid dan lipoprotein terjadi secara langsung dan kontinyu sehingga membuat sel fungi tersebut mengalami lisis. ${ }^{23-25}$

Hasil penelitian ini menunjukkan bahwa gas ozon dengan dengan waktu paparan 210 detik berpengaruh secara bermakna $(\mathrm{p}<0,005)$ dalam menurunkan jumlah koloni jamur $C$. albicans. Hal serupa dilaporkan Zargaran et al bahwa gas ozon mampu mereduksi konsentrasi mikroorganisme (strain C. albicans) dengan waktu paparan selama 30 detik hingga 210 detik. Hanya 150 detik dan isolat lain terhambat secara sempurna setelah terpapar gas ozon selama 210 detik. $^{26}$

Pada penelitian ini jumlah koloni jamur C. albicans yang digunakan sebagai densitas sampel yaitu $0,5-2,5 \times 10^{6} \mathrm{CFU} / \mathrm{mL}$ dan memberikan hasil bermakna dalam penghambatan pertumbuhan jamur $C$. albicans. Penelitian oleh Nikolic et $\mathrm{al}^{27}$ dengan menggunakan densitas sebanyak $1,0 \times 10^{4} \mathrm{CFU} / \mathrm{mL}$ serta $1,0 \times 10^{5} \mathrm{CFU} / \mathrm{mL}$ juga mendapatkan hasil bermakna pada penghambatan pertumbuhan jamur $C$. albicans. Yesil et $\mathrm{al}^{28}$ mengungkapkan bahwa densitas sel mikroorganisme berpengaruh pada konsentrasi dan waktu papar ozon. Semakin banyak jumlah koloni mikroorganisme uji maka sebagian dari koloni tersebut dapat terpapar ozon dengan cepat, sehingga konsentrasi ozon akan menurun di bawah ambang batas yang diperlukan untuk menonaktifkan jumlah mikroorganisme yang tersisa. Pada penelitian ini densitas sampel yang digunakan lebih besar daripada penelitian sebelumnya namun mesin generator ozon yang digunakan hanya menggunakan gas oksigen sebagai sumbernya sehingga proporsi gas oksigen lebih adekuat dan dapat mengasilkan ozon yang lebih berkualitas dibandingkan generator ozon yang menggunakan udara sebagai sumber gasnya. ${ }^{29}$

Penelitian ini menggunakan sampel berupa suspensi yang memiliki kandungan air di dalamnya. Hal ini sejalan dengan penelitian terdahulu yang mengungkapkan bahwa aktivitas air dari sampel dilaporkan memengaruhi efisiensi gas ozon. Sebagaimana dilaporkan Hoigne dan Bader $^{30}$ bahwa keberadaan air mampu mempercepat reaksi ozon dengan subtrat organik, sehingga efisiensi gas ozon berbanding lurus dengan aktivitas air dari sampel. ${ }^{31}$

Suhu yang digunakan untuk ozonasi suspensi jamur dalam penelitian ini sebesar $25^{\circ} \mathrm{C}$. Hal ini sejalan dengan penelitian yang dilakukan oleh Korzun et $\mathrm{al}^{32}$ yang telah membutikan keefektifan paparan gas ozon terhadap jumlah koloni jamur pada suhu $25^{\circ} \mathrm{C}$. Suhu memiliki pengaruh linier terhadap efisiensi gas ozon, dimana pada suhu tinggi dijumpai aktivitas merusak spora semakin tinggi dan laju oksidasi jamur meningkat seiring peningkatan suhu. ${ }^{31}$

Pada penelitian ini, $\mathrm{pH}$ yang digunakan dalam suspensi $C$. albicans ialah 7,2 yang memberikan pengaruh bermakna terhadap penurunan jumlah koloni jamur tersebut. Penelitian relevan mengenai $\mathrm{pH}$ terhadap efisiensi gas ozon belum banyak dilakukan. Prasetyaningrum et $\mathrm{al}^{33}$ melaporkan bahwa peningkatan $\mathrm{pH}$ akan meningkatkan konsentrasi ozon terlarut, dan konsentrasi ozon tertinggi dijumpai pada $\mathrm{pH}$ 7-8. Telah diketahui $\mathrm{pH}$ memengaruhi koefisien tranfer massa ozon dari fase gas ke fase cair. Namun, peningkatan nilai $\mathrm{pH}$ di atas 8 akan membuat konsentrasi ozon terlarut semakin menurun. ${ }^{33}$ Hal tersebut mendukung penelitian ini yaitu $\mathrm{pH}$ 7,2 masih termasuk dalam rentang $\mathrm{pH}$ optimal dari gas ozon sehingga memengaruhi paparan gas ozon dalam mem- 
berikan efek bermakna terhadap penurunan jumlah koloni jamur C. albicans.

Pardeep et $\mathrm{al}^{34}$ mengungkapkan bahwa masih sedikit dokumentasi mengenai penelitian klinis yang membuktikan potensi ozon di bidang kedokteran gigi. Penelitian yang dilakukan oleh Talmac et $\mathrm{al}^{35}$ melaporkan bahwa terapi ozon yang ditambahkan pada terapi periodontal secara bermakna memperbaiki parameter klinis pada perokok dan nonperokok. Monzillo et $\mathrm{al}^{25}$ mengungkapkan bahwa meskipun telah dilakukan penelitian pada beberapa aspek di kedokteran gigi, namun eksplorasi mengenai potensi fungisida dari terapi ozon masih terbatas. ${ }^{25.35}$

Keterbatasan penelitian ini ialah desain penelitian yang digunakan belum mampu mengetahui efisiensi dari gas ozon terhadap jumlah koloni jamur $C$. albicans yang dilaku-kan dengan generator ozon dari Universitas Diponegoro karena penelitian ini dilakukan tanpa adanya pembanding berupa obat kumur antiseptik standar yang direkomendasikan dalam praktik kedokteran gigi, seperti klorheksidin, povidon iodin, maupun hidrogen peroksida. ${ }^{36}$ Penelitian ini cukup menjawab hipotesis mengenai adanya pengaruh dari paparan gas ozon terhadap jumlah koloni jamur $C$. albicans. Selain itu, tidak terdapat variasi waktu dan konsentrasi paparan gas ozon pada penelitian ini sehingga tidak diketahui waktu dan konsentrasi minimal dari penghambatan pertumbuhan jamur C. albicans.

\section{SIMPULAN}

Paparan gas ozon berpengaruh secara signifikan terhadap penurunan jumlah koloni jamur Candida albicans.

\section{Konflik Kepentingan}

Penulis menyatakan tidak terdapat konflik kepentingan dalam studi ini.

\section{DAFTAR PUSTAKA}

1. Singh SR, Krishnamurthy NB, Mathew BB. A review on recent diseases caused by microbes. J Appl Environ Microbiol. 2014;2(4):106-15.

2. Giesecke J. Modern Infectious Disease Epidemiology. London: CRC Press, 2017.
3. Fuerst J. Microorganisms - A journal and a unifying concept for the science of microbiology. J Microorganism. 2014; 2(4):140-6.

4. Köhler JR, Casadevall A, Perfect J. The spectrum of fungi that infects humans. Cold Spring Harb Perspect Med. 2015;5(1):1-22.

5. Suryaningsih A, Chumaeroh S, Benyamin B. Uji efektifitas ekstrak anggur merah (Vitis vinivera) terhadap Pertumbuhan Candida albicans secara in vitro. Medali $\mathrm{J}$. 2015;2(1):5-8.

6. Ibrahim NK, Alwafi HA, Sangoof SO, Turkistani AK, Alattas BM. Crossinfection and infection control in dentistry: knowledge, attitude and practice of patients attended dental clinics in King Abdulaziz University Hospital, Jeddah, Saudi Arabia. J Infect Public Health. 2017;10(4):438-45.

7. Australian Dental Association. Guidelines for Infection Control (3nd ed). New South Wales: Australian Dental Association Press, 2015.

8. Damasceno JL, Santos RA Dos, Barbosa AH, Casemiro LA, Pires RH, Martins CHG. Risk of fungal infection to dental patients. Sci World J. 2017;2017. Article ID 2982478. Available from: https://doi.org/10.1155/2017/2982478

9. Krishnan AP. Fungal infections of the oral mucosa. Indian J Dent Res. 2012;23(5): 650-9.

10. Patil S, Rao RS, Sanketh DS, Amrutha N. Microbial flora in oral diseases. $\mathrm{J}$ Contemp Dent Pract. 2013;14(6):1202-8.

11. Merino-Alado RL, Garcés A, Chianale E, Corcuera C, Fakih W El, Galviz D, et al. Isolation of fungi and gram negative bacteria from toothbrushes and bathroom bioaerosols. Pesqui Bras Odontopediatria Clin Integr. 2018;18(1):1-10.

12. Robinson DS, Bird DL. Essentials of Dental Assisting. Missouri: Elsevier Health Sciences, 2016.

13. Błochowiak KJ. Dental treatment and recommended management in patients at risk of infective endocarditis. Kardiochirurgia i Torakochirurgia Pol. 2019; 16(1):37-41.

14. Shin AR, Nam SH. The effects of various mouthwashes on the oral environment change for oral health care. Biomed Res. 2018;29(8):1724-9. 
15. Karkowska-Kuleta J, Rapala-Kozik M, Kozik A. Fungi pathogenic to humans: Molecular bases of virulence of Candida albicans, Cryptococcus neoformans and Aspergillus fumigatus. Acta Biochim Pol. 2009;56(2):211-24.

16. Parashar A. Mouthwashes and their use in different oral conditions. Sch J Dent Sci J Dent Sci. 2015;2(2):186-91.

17. Iakovides IC, Michael-Kordatou I, Moreira NFF, Ribeiro AR, Fernandes T, Pereira MFR, et al. Continuous ozonation of urban wastewater: removal of antibiotics, antibiotic-resistant Escherichia coli and antibiotic resistance genes and phytotoxicity. Water Res J. 2019;159:333-47.

18. Saini R. Ozone therapy in dentistry: a strategic review. J Nat Sci Biol Med. 2011;2(2): 151-3.

19. Galdeano MC, Wilhelm AE, Goulart IB, Tonon RV, Freitas-Silva O, Germani R, et al. Effect of water temperature and $\mathrm{pH}$ on the concentration and time of ozone saturation. Brazilian J Food Technol. 2018;21:1-7.

20. Zain AZ, Restiwijaya M, Hendrini AR, Dayana B, Yulianto E, Kinandana AW, et al. Development of ozone reactor for medicine base on dielectric barrier discharge (DBD) plasma. J Phys Conf Ser. 2019;1153(1).

21. Dahlan MS. Statistik untuk Kedokteran dan Kesehatan: Deskriptif, Bivariat dan Multivariat, Dilengkapi dengan Menggunakan SPSS. Jakarta: Salemba Medika, 2009.

22. Gupta G, Mansi B. Ozone therapy in periodontics. J Med Life. 2012;5(1):59-67.

23. Di Mauro R, Cantarella G, Bernardini R, Rosa M Di, Barbagallo I, Distefano A, et al. The biochemical and pharmacological properties of ozone: the smell of protection in acute and chronic diseases. Int J Mol Sci. 2019;20(3):634.

24. Smith N, Wilson A, Gandhi J, Vatsia S, Khan S. Ozone therapy: an overview of pharmacodynamics, current research, and clinical utility. Med Gas Res. 2017; 7(3):212-9.

25. Monzillo V, Lallitto F, Russo A, Poggio C, Scribante A, Arciola CR, et al. Ozonized gel against four candida species: a pilot study and clinical perspectives. Materials (Basel). 2020;13(7):1-7.
26. Zargaran M, Fatahinia M, Zarei Mahmoudabadi A. The efficacy of gaseous ozone against different forms of Candida albicans. Curr Med Mycol. 2017;3(2): 26-32.

27. Nikolić M, Glamočlija J, Ćirić A, Perić T, Marković D, Stević T, et al. Antimicrobial activity of ozone gas and colloidal silver against oral microorganisms. Dig J Nanomater Biostructures. 2012;7(4):1693-9.

28. Yesil M, Kasler DR, Huang E, Yousef AE. Efficacy of gaseous ozone application during vacuum cooling against Escherichia coli $\mathrm{O} 157: \mathrm{H7}$ on spinach leaves as influenced by bacterium population size. $\mathbf{J}$ Food Prot. 2017; 80(7):1066-71.

29. Cuong LC, Nghi NH, Dieu TV, Oanh DTY, Vuong DD. Influence of oxygen concentration, feed gas flow rate and air humidity on the output of ozone produced by corona discharge. Vietnam J Chem. 2019;57(5):604-8.

30. Hoigné J, Bader H. Rate constants of reactions of ozone with organic and inorganic compounds in Water-I. Non-dissociating organic compounds. Water Res J. 1983;17(2):173-83.

31. Allen $\mathrm{B}, \mathrm{Wu} \mathrm{J}$, Doan $\mathrm{H}$. Inactivation of fungi associated with barley grain by gaseous ozone. J Environ Sci Heal - Part B Pestic Food Contam Agric Wastes. 2003;38(5): 617-30.

32. Korzun W, Hall J, Sauer R. The effect of ozone on common environmental fungi. Am Soc Clin Lab Sci. 2008;21(2):107-11.

33. Prasetyaningrum A, Kusumaningtyas DA, Suseno P, Ratnawati R. Effect of $\mathrm{pH}$ and gas flow rate on ozone mass transfer of K-Carrageenan solution in bubble column reactor. REAKTOR. 2019; 18(04):177.

34. Pardeep S, Kirtika S, Neha S, Nidhi D. Review of ozone and its role in prosthodontics. Sch J Dent Sci. 2017;4(5):226-32.

35. Talmaç AC, Çalişir M. Efficacy of gaseous ozone in smoking and non-smoking gingivitis patients. Ir J Med Sci. 2020.

36. Kementerian Kesehatan Republik Indonesia. Standar Pencegahan dan Pengendalian Infeksi Pelayanan Kesehatan Gigi dan Mulut di Fasilitas Pelayanan Kesehatan. Jakarta: Depkes RI, 2012. 